\title{
The impact of climate change and plantation development on streamflow in the Denmark River catchment, Western Australia
}

\author{
M. A. Bari ${ }^{1}$, R. P. Silberstein ${ }^{2}$, S. K. Aryal ${ }^{2}$ \\ ${ }^{1}$ Climate and Water Division, Bureau of Meteorology, PO Box 1370, West Perth, W.A. 6872. \\ ${ }^{2}$ CSIRO Land and Water, Private Bag No. 5, Wembley WA 6913. \\ E-mail: m.bari@bom.gov.au
}

\begin{abstract}
The Denmark River is located in the southern coast of Western Australia and is an important water source for the Albany-Denmark Region, yielding up to 20 gigalitres (GL) per year. The river has had significant salinity issues due to clearing of native vegetation. The Quickup River dam was built in 1990 as an alternative water supply source for the town of Denmark; however in recent years it has not been able to supply enough water to meet demand. A target has been set to recover the Denmark River to potable water standards by 2020. Since 1990, commercial tree plantations have been established in the upper, high salt storage low-runoff, part of the catchment. Further plantings have been promoted as a means of reducing the salinity of the river.
\end{abstract}

The Land Use Change Incorporated CATchment (LUCICAT), a distributed dynamic conceptual model, was used to assess the impact on streamflow and salinity due to climate and tree planting on future water yield. Three scenarios were modelled: (i) the historical sequence representing the 1975-2007 climate, (ii) recent climate representing the 1997-2007 climate, and (iii) future climate representing a 33-year climate series derived from different GCM projections of 2030 climate.

Results showed that there would be about a 13\% reduction in streamflow by 2030 due to tree planting in the upper part of the catchment under a continuation of the historical climate. If the recent climate continues there would be no significant change in streamflow as the average rainfall is similar to the 1975-2007 period. Under the future climate projections the projected reduction in streamflow would be $34 \%$, ranging from $17 \%$ to $55 \%$ respectively due to a projected reduction in mean annual rainfall of $6.7 \%$ (range: $2.5 \%$ to $13 \%$ ). However, projected streamflow reductions were even higher in the Yate Flat Creek catchment, where plantations were established in the late 1990s covering nearly all the cleared areas. The daily flow-duration of the catchment was about $77 \%$ during the historical period, and is projected to decrease to only $20-27 \%$ in future due to climate change and plantation development.

Keywords: Denmark River, LUCICAT model, Climate change, Reforestation, Water yield, Rainfall-Runoff modeling. 
Bari et al., The impacts of climate change and plantation development on streamflow in the Denmark River catchment, Western Australia

\section{INTRODUCTION}

Coastal and estuarine environments in south west of Western Australia (SWWA) have high economic, environmental and cultural values. They support a rich diversity of habitats, which sustain regional economies through tourism and other industries. Increased population pressure and degradation of water resources due to earlier deforestation along the south coast of WA have impacted the estuarine ecosystems in the region and the economies and communities they support. The Denmark River (Figure 1) is located in the Great Southern region of Western Australia and is an important water source for the Albany-Denmark Region, yielding up to 20 gigalitres (GL) per year. However, increased salinity in the Denmark River has resulted in abandonment of water from the river as a source of municipal water supply. This has put pressure on the nearby Quickup River dam which has been unable to meet its water demand.

In recent years, efforts have been made to return the Denmark River to potable water standards by 2020 . Since 1990, commercial tree plantations have been successfully established in the upper, high salt storage low-runoff, part of the catchment. Further plantings have been promoted as a means of reducing the salinity of the river.

Given the changed climate regime since mid 1970s in SWWA, this paper explores impacts on streamflow and salinity due to climate and tree planting on future water yield in the Denmark River. Three scenarios were modelled: (i) the historical sequence representing the 1975-2007 climate (Scenario A), (ii) recent climate representing the 1997-2007 climate (Scenario B), and (iii) future climate representing a 33-year climate series derived from different GCM projections of 2030 climate (Scenario C).

The Land Use Change Incorporated CATchment (LUCICAT), a semi-distributed dynamic conceptual model (Bari and Smettem 2006), was used to perform the modelling. This paper describes the finding from the modelling.

\section{CATCHMENT DESCRIPTION}

The Denmark catchment covers an area of $500 \mathrm{~km}^{2}$, and through 1975 to 2002 has had an annual rainfall of $790 \mathrm{~mm}$ and streamflow of 28.4 GL equating to a runoff of $56 \mathrm{~mm}$ (Bari et al., 2004). Mean annual potential evaporation is about $1400 \mathrm{~mm}$ (Luke et al., 1988). More than $40 \%$ of the upper Denmark catchment was cleared by the 1970s and the river water became too saline for public water supply (500-1000 mg/L TDS, 1985 to 2002) (Bari et al., 2004). To address salinity, clearing controls were introduced in 1978 and, following plantation establishment, the Denmark River was the first SWWA river to show improvement in salinity due to human intervention (Bari et al., 2004).

\section{METHOD}

We investigated the potential impacts of

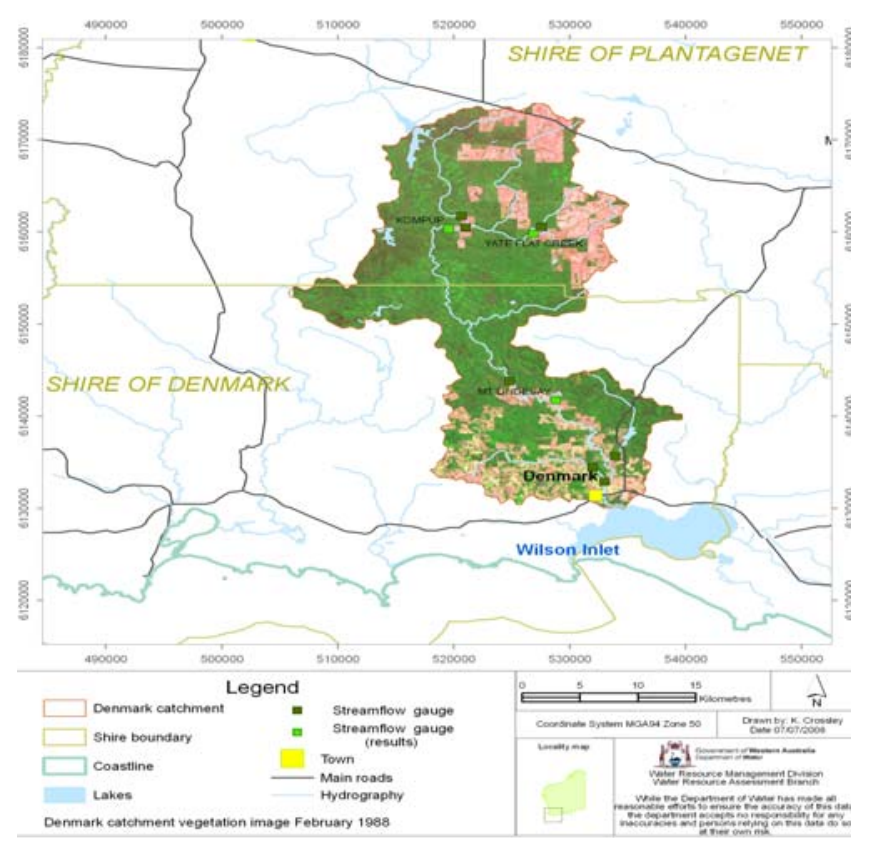

Figure 1. Location of the Denmark River catchment (after Smith et al., 2009). projected climate change and reforestation on the water availability of the Denmark River catchment in Western Australia by 2040 using the LUCICAT rainfall runoff model. The three main components to this study were: (a) calibration of the LUCICAT model, (b) simulation of the impacts of projected scenarios and (c) analysis and assessment of the projected streamflow data. In all three scenarios plantations were assumed to be ‘fully-grown' by 2008.

\subsection{Scenarios}

The climate scenarios and generation of synthetic climates from GCM forecasts are described in more detail elsewhere (Charles et al, 2009). Scenario A is based on the historical climate sequence where rainfall and potential evaporation (PE, calculated following Morton's reference evapotranspiration, (1983)) for 19752007 was repeated from 2008 onward until 2040. Under this scenario, surface water allocations remained 
Bari et al., The impacts of climate change and plantation development on streamflow in the Denmark River catchment, Western Australia

unchanged at the 2007 level. This is consistent with the current planning of the Department of Water in Western Australia. The second scenario (B) based on 'recent climate' - rainfall and PE data of last 11 years (1997-2007) were repeated three times from 2008 to 2040. It was used to assess the water availability in the future if the climate remains similar to the current decade. The third scenario $(\mathrm{C})$ is based on the projections by $15 \mathrm{GCMs}$ for a low $\left(0.7^{0} \mathrm{C}\right)$, medium $\left(1.0^{\circ} \mathrm{C}\right)$ and high $\left(1.3^{0} \mathrm{C}\right)$ global warming relative to the 1990 climate (CSIRO, 2009), and is representative of 2030s climate. The projected increases in temperature and changes in rainfall and other variables were used to scale the historical climate to generate future climate sequences of 45 runs (Charles et al., 2009). Land use and water allocations remained unchanged for all three scenarios. Results are presented for a "wet", "mid" and "dry" future climate selected as the $5^{\text {th }}$ wettest, the median and $5^{\text {th }}$ driest of the 45 runs (referred to as $C_{\text {wet }}, C_{\text {mid }}$ and $C_{\text {dry }}$ respectively). Note the "wet" scenario is not generally wetter than the historical, it is the wettest of the future scenarios presented.

\section{MODEL CALIBRATION}

\subsection{The LUCICAT model}

The LUCICAT model is a semi-distributed hydrological model. Generally a large catchment is divided into smaller Response Units (RU) to take into account the spatial distribution of rainfall, evaporation and land use. Each RU is represented by a simple V-shaped hill-slope configuration and a fundamental 'buildingblock' model is applied. Catchment attributes such as soil depth, rainfall, pan evaporation, land use change and groundwater levels are incorporated into the 'building-block' model (Bari \& Smettem 2006a, b). The building-block model consists of five inter-connecting stores: (i) Dry, Wet and Subsurface stores, (ii) a saturated Groundwater Store, and (iii) a transient Streamzone Store. The transient Streamzone Store represents the groundwater induced 'saturated areas' along the stream zone. The fluxes between the Dry, Wet and Subsurface Stores represent the water movement in the unsaturated zone. The dynamically varying saturated stream zone areas are responsible for surface runoff. The Groundwater Store controls the groundwater flux to stream zone. Generated flow from each of the RU is routed downstream by the Muskingum-Cunge routing scheme which also computes the daily water balance of the lakes and reservoirs.

\subsection{Calibration}

The model application consists of a few steps - data preparation, delineating the RU, calibration and validation. The catchment was divided into 58 RUs, based on digital elevation model data. Daily rainfall and Morton Wet Surface Potential Evaporation (Morton, 1983) series on a $5 \mathrm{~km}$ grid was obtained from the Bureau of Meteorology and Queensland Department of Natural Resources' SILO data set (http://www.longpaddock.qld.gov .au/silo/) and then calculated for each of the RU using the reciprocal distance weighting method. Response Unit attributes, stream characteristics, surface topography, land use history and Leaf Area Indices were computed using ArcGIS.

The LUCICAT Live framework provides a visual interface for LUCICAT calibration and simulation runs (Bari et al., 2009). The model was calibrated for all catchments by trial and error based on statistical criteria including Nash-Sutcliffe Efficiency (NSE), Correlation Coefficient (CC), Explained Variance (EV), Flow-period Error Index (EI) and Water Balance Error (E). For daily streamflow CC, EI and E were in the range of 0.5-1.0, 0.7-1.2 and \pm 0.10 respectively for all seven gauging 
Bari et al., The impacts of climate change and plantation development on streamflow in the Denmark River catchment, Western Australia

stations within the catchment and were significantly better for monthly and annual flows. The comparison of the observed and predicted streamflow at the Mt Lindesay gauging station is shown in Figure 2 as an example. The observed and predicted annual average streamflow was 29 GL and 30 GL respectively. The modeled mean annual runoffs from all 10 gauging stations were within \pm 0.10 of the observed flows. The model predicted the low ( $10^{\text {th }}$ percentile) and high $\left(90^{\text {th }}\right.$ percentile) matched very well with observed streamflow of all gauging stations.

\subsection{Post audit}

The LUCICAT model was audited by analysing temporal trends in prediction errors (the difference between predicted and observed annual runoff). Errors in annual runoffs were analysed for most of the gauging stations based on: (1) no significant land use change, and (2) large amount of forest clearing and tree planting. In most of the cases there were no time trends in error distributions. The Perillup gauging station recorded streamflow during the period (1962-72), when there was no significant forest clearing or reforestation. While at the Yate Flat Creek catchment, there were large cleared areas most of which were replanted by the early 2000s. Although there was considerable change in the rainfall-runoff relationship in the Yate Flat Creek catchment, error distribution was well-balanced and no trends were found, indicating that the model represented non-stationary land use and rainfall changes very well.

\section{CLIMATE CHANGE PROJECTIONS}

The calibrated LUCICAT model was then run to assess the impacts of climate change and land use change scenarios on streamflow. The rainfall and Morton PE data was extended to 2040 and all the scenarios were introduced in 2008. The Leaf Area Indices and land use remained unchanged and assumed to reach maturity from 2008 onward.
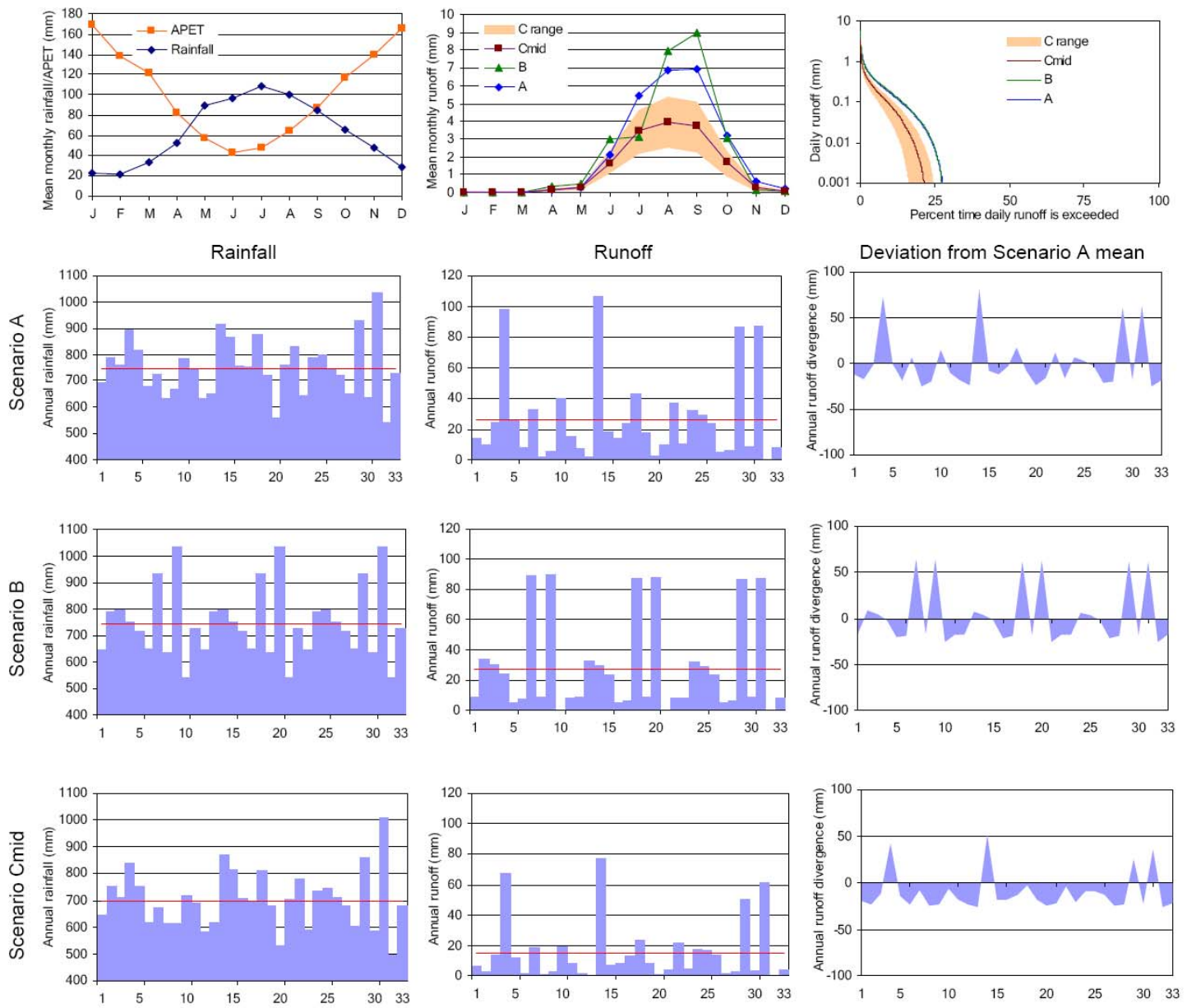

Figure 3. Climate change scenarios and reduction in runoff - Yate Flat Creek catchment. 
Bari et al., The impacts of climate change and plantation development on streamflow in the Denmark River catchment, Western Australia

\subsection{Rainfall}

Under Scenario A rainfall statistics during 2008-2040 remain the same as 1975-2007. However, under the 'recent climate' scenario (B) the mean annual rainfall (2008-2040) is slightly lower than from 1975-2007 in some gauged sub-catchments, with the largest decline $(\sim 1.5 \%)$ being in the Kompup and Yate Flat Creek catchments. Under the three different warming scenarios average annual rainfall reductions were 6, 9 and $12 \%$ respectively. The largest projected reduction of $\sim 80 \mathrm{~mm}$ would be at the sub-catchments closer to the town of Denmark.

\subsection{Climate change and reforestation}

Reforestation is an important feature of salinity management in the Denmark River catchment (Bari et. et. al, 2004). Most of the cleared areas in the Kompup and Yate Flat Creek catchments were planted with trees in the mid-1990s, particularly for stream salinity control and management (see Figure 1 for locations). In some of the reforested catchments, particularly Yate Flat, runoff was considerably lower under the historical climate scenario (A) than during the calibration period, which could be attributed to the higher LAI in 2007 and greater proportion of cleared area planted (Table 1), which were kept unchanged for the 2008-2040 projection period. Most of the cleared areas in the Yate Flat Creek catchment were reforested in the late 1990s (Bari et al., 2004). Daily flow-duration was projected to decrease from about $77 \%$ under the historical period to approximately $20-27 \%$ under all future climate scenarios and reforestation (Figure 3). Results are similar to other applications of the model (Dixon and Bari, 2008; Kitsio et al., 2008; Smith et al., 2006; Charles et al., 2007).

Table 1 Main gauging stations, land use and Scenario results

\begin{tabular}{|c|c|c|c|c|c|c|c|c|c|}
\hline \multirow[t]{2}{*}{ Catchment } & \multirow[t]{2}{*}{ Land use } & \multirow[t]{2}{*}{ Trend } & \multicolumn{7}{|c|}{ Mean annual runoff (mm) } \\
\hline & & & $\begin{array}{l}\text { D্d } \\
\sum_{0}^{\infty} \\
0\end{array}$ & 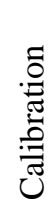 & 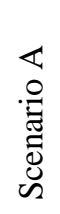 & 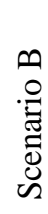 & 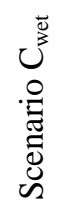 & 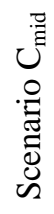 & 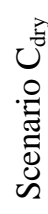 \\
\hline $\begin{array}{l}\text { Lindesay } \\
\text { Gorge }\end{array}$ & $\begin{array}{l}\text { Clearing of } \sim 11 \% \text { of the catchment } \\
\text { area during } 1950-77 \text {. Operational } \\
\text { logging, forest fire and regeneration }\end{array}$ & None & 46 & 48 & 42 & 42 & 35 & 27 & 18 \\
\hline Kompup & $\begin{array}{l}\text { Clearing of } \sim 19 \% \text { of the catchment } \\
\text { area, more than } 30 \% \text { of the cleared } \\
\text { areas were planted }\end{array}$ & None & 48 & 46 & 22 & 21 & 17 & 12 & 8 \\
\hline Mt Lindesay & $\begin{array}{l}\text { Clearing of } \sim 12 \% \text { of the catchment } \\
\text { areas, more than } 50 \% \text { were planted. }\end{array}$ & None & 57 & 61 & 53 & 54 & 44 & 35 & 24 \\
\hline $\begin{array}{ll}\text { Yate } & \text { Flat } \\
\text { Creek } & \end{array}$ & $\begin{array}{l}\text { Clearing or } \sim 33 \% \text { of the catchment } \\
\text { area, more than } 60 \% \text { of the cleared } \\
\text { areas were planted }\end{array}$ & None & 81 & 81 & 26 & 27 & 21 & 15 & 9 \\
\hline
\end{tabular}

The impacts of lower rainfall under the future climate scenarios are also evident in conceptual groundwater levels and catchment storages. Both the groundwater level and catchment-average soil water storage declined in scenarios B and C (Figure 4). The conceptual groundwater level declines under the native forest and planted areas in the range of 0.4 to $0.9 \mathrm{~m}$. Similar trends are also evident in the reduction of catchment average soil water storage. The soil water storage of most of the Response Units appears to have stabilized by 2030.

In general, flow durations are projected to decrease in all gauging stations under all future climate scenarios (an example is shown in Figure 4). Reduction in flow-duration has implications on environmental water allocations, stream zone ecology, flora and fauna. 


\subsection{Streamflow and catchment storage}

As the rainfall changes under the 'Recent Climate' (Scenario B) are not large, the projected changes in streamflow at the Mt Lindesay gauging station were minimal as well; - 27.2 GL compared to 26.7 GL under Scenario A. Under Scenario C a large range of reductions in streamflow were found, mainly due to variations in 15 GCMs' rainfall projections. Nearly all GCMs projected lower rainfall in all future scenarios meaning lower streamflows as well. Streamflow response to different climate scenarios at the Yate Flat Creek catchment is shown as an example (Figure 3). Monthly runoff is projected to decline under future climates, the largest being in July-August when most of the runoff is being generated, and only in a few years is annual runoff projected to exceed mean (1975-2007) runoff

(Figure 3). Under scenario $\mathrm{C}_{\mathrm{dry}}$,

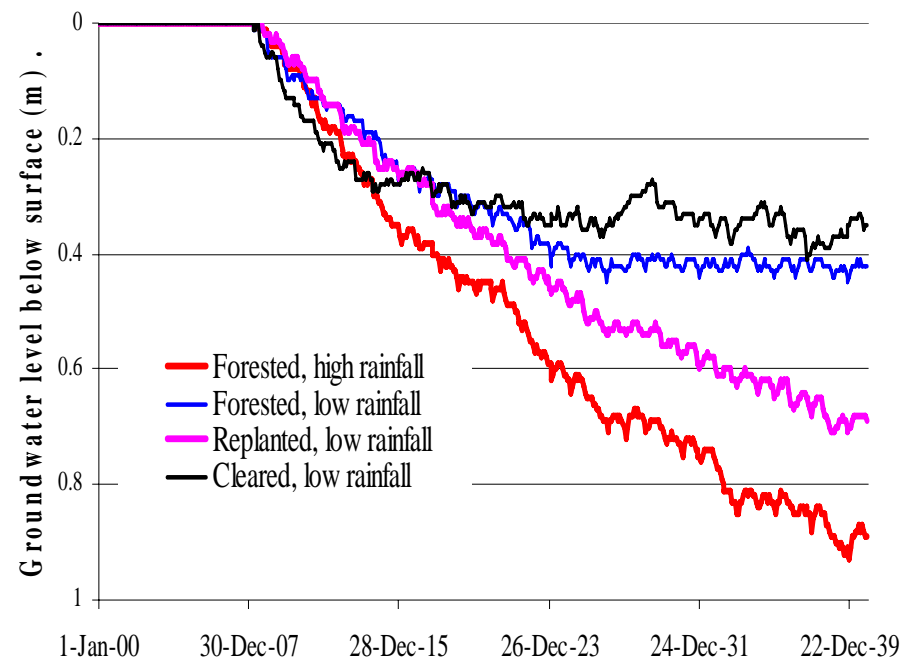

Figure 4. Reduction in conceptual groundwater level under Scenario $\mathrm{C}_{\text {mid }}$ relative to under Scenario A.

( $5^{\text {th }}$ driest of all 45 scenario $C$ runs) projected runoff reductions at four gauging stations range from 55 to $67 \%$ below that under Scenario A (Table 1). In the case of $C_{\text {wet }}\left(5^{\text {th }}\right.$ wettest of all Scenario $C$ runs) mean runoff is projected to decline by 17 to $23 \%$ at the four gauging stations. If the median climate prevails in the future $\left(\mathrm{C}_{\text {mid }}\right)$, streamflow at Mt Lindesay gauging station is projected to be $34 \%$ lower (to $18 \mathrm{GL}$ ) and in only a few years would the projected annual streamflow exceed that under Scenario A.

\section{SUMMARY AND CONCLUSIONS}

A semi-distributed rainfall-runoff model, LUCICAT, was calibrated against observed data at major gauging stations within the Denmark River catchment. The predicted streamflow was within $\pm 10 \%$ of the observed data for all the gauged sub-catchments. The observed and calibrated mean annual streamflow at the Mt Lindesay, main gauging station of the catchment, was 29 GL and 31 GL respectively.

Three climate change scenarios were defined to project future catchment yield. The historical rainfall during 1975-2007 was extended and was considered as the reference base case (Scenario A). The second scenario (B) represented the more recent 1997-2007 climate and was repeated 3 times to represent climate to 2040 . For all gauged sub-catchments, scenario B rainfall was just slightly less than the 1975-2007 mean with the largest reduction $(\sim 1.5 \%)$ being in the Kompup catchment, where most of the reforestation took place. The third scenario (C) represents future climates of projections from 15 GCMs for each of low $\left(0.7^{0} \mathrm{C}\right)$, medium $\left(1.0^{\circ} \mathrm{C}\right)$ and high $\left(1.3^{0} \mathrm{C}\right)$ global warming by 2030 . Rainfalls in the catchment were projected to decrease by 6,9 and $12 \%$ for these three warming levels respectively.

The calibrated LUCICAT model was then used to simulate the streamflow for each scenario. Under Scenario A streamflow was slightly different from the calibration period. The differences were mainly due to the recent plantations in the Yate Flat Creek and Kompup catchments reaching maturity and a static LAI simulated from 2007 onward. Under Scenario A, the model predicted a large reduction in streamflow particularly at the Kompup and Yate Fat Creek, mainly due to establishment of plantations covering most of the cleared areas. Under the recent climate (Scenario B) mean annual streamflow at Mt Lindesay, the mostdown stream gauging station, would be $27.2 \mathrm{GL}$ compared to $26.7 \mathrm{GL}$ of Scenario A. On average the annual inflow to Mt Lindesay under median climate change scenario $\left(C_{\text {mid }}\right)$, was predicted to be approximately $34 \%$ (18 GL) lower than Scenario A. But the reduction in runoff is not projected to be uniform across the catchment. The largest proportional reduction is projected to be at the low rainfall-runoff generating par of the catchment. 
Bari et al., The impacts of climate change and plantation development on streamflow in the Denmark River catchment, Western Australia

\section{ACKNOWLEDGMENTS}

We thank Steve Charles (CSIRO) for climate sequences and Geoff Mauger (GIA Ltd) for model preparation and data analyses. The Department of Water developed an earlier version of the LUCICAT model for this catchment for salinity recovery work. We also acknowledge two reviewers whose feedback improved this paper. Much of this work was funded by the Australian Government through the Department of Environment, Water, Heritage and the Arts under the Southwest Western Australia Sustainable Yields project.

\section{REFERENCES}

Bari, M.A., Mauger, G.W., Dixon, R.R.M., Boniecka, L.H., Ward, B., Sparks, T. and Waterhouse, A.M., 2004. Salinity Situation Statement: Denmark River, Water and Rivers Commission, Water Resource Technical Series No. WRT 30.

Bari, M.A., Shakya, D.M. and Owens, M. (2009), LUCICAT Live - A modelling framework for predicting catchment management options, In MODSIM 2009, Cairns, July 2009, Australia.

Bari, M.A. and Smettem, K.R.J. (2006a), A conceptual model for daily water balance following partial clearing from forest to pasture, Hydrol. Earth Syst. Sci., 10, 321-337.

Bari, M.A. and Smettem, K.R.J., (2006b). A daily salt balance model for stream salinity generation processes following clearing from forest to pasture, Hydrol. Earth Syst. Sci, 10, 519-534.

Charles, S.P., Bari, M.A., Kitsios, A. and Bates, B.C. (2007), Effects of GCM bias on downscaled precipitation and runoff projections for the Serpentine catchment, Western Australia, Int. J. Climatol., 27, 1673-90.

Charles, S.P., Silberstein, R.P., Chiew, F.H.S., Viney, N.R., Teng, J., Yang, A., Van Niel, T., and Smith, I., 2009 Future Climate Scenarios for the South-West Western Australia, Sustainable Yields Project. CSIRO.

CSIRO(2009), Surface water yields in south-west Western Australia, A report to the Australian Government from the CSIRO South-West Western Australia Sustainable Yields Project, CSIRO, Australia.

Dixon, N.R.M and Bari, M.A. (2008), Modelling of Stream Salinity Management Options for the Warren River, In: Hydrology and Water Resources Symposium, The Institution of Engineers, Adelaide, Australia, 2008.

IOCI (2002), Climate variability and change in south-west Western Australia, Indian Ocean Climate Initiative, 34p.

Kitsios, A., Bari, M.A. and Charles, S.P. (2008), Projecting impacts of climate change on the Serpentine catchment - Donscaling from multiple General Circulation Models, Department of Water, Western Australia, Water Resource Technical Series, No. WRT36, 87p.

Luke, GJ, Burke, KL \& O’Brien, TM 1988, Evaporation data for Western Australia, Western Australia Department of Agriculture, Division of Resource Management, Technical report, no. 65, pp. 29.

Morton, F.I. (1983), Operational estimates of areal evapotranspiration and their significance to the science and practice, J. of Hydrology, J. Hydrol., 66, 1-76.

Smith, K., Boniecka, L., Bari, M.A. and Charles, S.P. (2009). The impact of climate change on rainfall and streamflow in the Denmark River catchment, Western Australia, Department of Water, Water Resource Assessment Branch, Rep. HY30, 58p 